\title{
Daniel Senise: pintura como abrigo da imagem
}

RESUMO: Daniel Senise é um dos mais emblemáticos pintores da chamada "Geração 80" no Brasil. A partir da obra de Senise, este ensaio procura entender a arte egressa dos 1980 não apenas como a "volta da pintura" — o retorno conservador a um tipo de linguagem ou suporte — , e sim como o reestabelecimento de uma relação mais íntima com a imagem. O artista recorre a figuras de mães, mulheres e construções arquitetônicas para enfatizar a criação de um abrigo para as imagens da história da arte ou de elementos cotidianos, cuja escolha é orientada pela memória e pelo afeto. Com apagamentos e ausências, sua obra evidencia o encerramento e o reinício de ciclos para essas imagens.

PALAVRAS-CHAVE: Daniel Senise; Geração 80; pintura; imagem.

ABSTRACT: Daniel Senise is one of the most emblematic artists of the "Geração 80" (Generation 80 ) in Brazil. With the analysis of Senise's work, this essay seeks to understand the art of 1980 not as the "back of the paiting" - a conservative return to a kind of language or support - , but as the re-establishment of a closer relationship with the image. The artist uses pictures of mothers, women and architectural constructions to emphasize the creation of a shelter for the images from History of Art or everyday elements, whose choice is guided by memory and affection. With deletions and absences, his work highlights the close and restart cycles for these images.

KEYWORDS: Daniel Senise; Geração 80 (Generation 80); painting; image.

\footnotetext{
*Daniela Name é crítica de arte e curadora. Doutoranda da linha de Tecnologias da Comunicação e Estéticas da Escola de Comunicação da UFRJ, pesquisa relações entre palavra e imagem na arte contemporânea brasileira a partir da obra de Cildo Meireles. É mestre em História e Crítica da Arte pela EBA-UFRJ, onde defendeu a dissertação "Geração de afetos", sobre a arte brasileira dos anos 1980. Autora dos livros Almir Mavignier (2013), Norte/Marcelo Moscheta (2014) e Amelia Toledo - Forma fluida (2015).
} 
O beijo do elo perdido, de 1991, é um dos mais conhecidos trabalhos de Daniel Senise. No centro da composição, dois crânios de pássaro, fósseis de um tempo que já não é mais, ganham vida nova ao se enlaçarem em um beijo. O fundo da pintura não é neutro: tratado como paisagem, parece uma imensidão de areia, um lugar "no meio do nada". Pintado com tinta acrílica sobre cretone - tecido mais fino que a tela tradicional, que Senise passou a usar com frequência a partir do final da década de 1980 - o trabalho tem marcas, que são como cicatrizes em pedaços onde a tinta foi arrancada. Traz também manchas de outras cores em tons de terra e cinza, além de uma inscrição, no canto inferior direito, que parece o início de uma palavra no espelho, invertida: "ANGE".

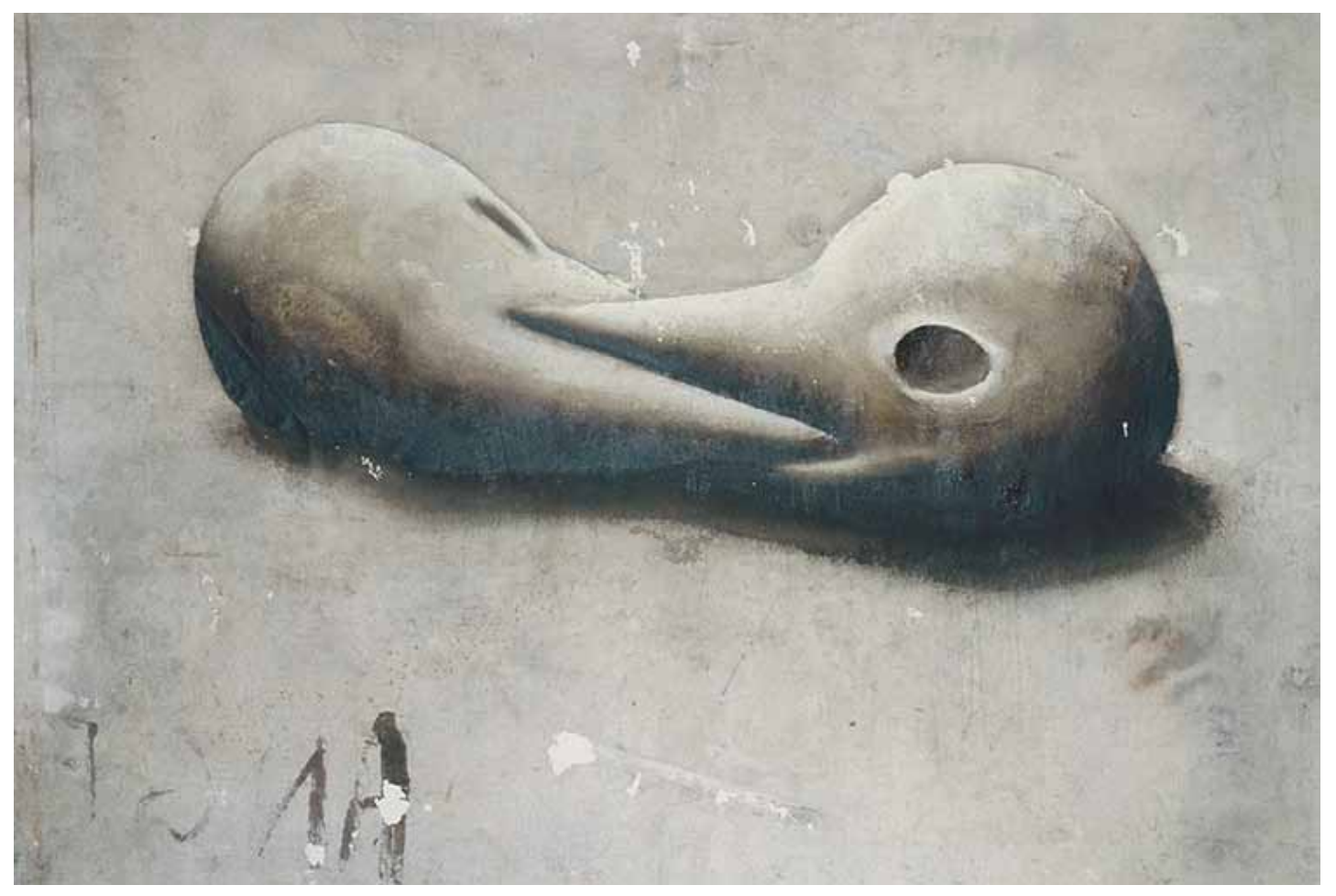

\section{Daniel Senise}

O beijo do elo perdido, 1991

Acrílica e óleo sobre cretone, $139 \times 203 \mathrm{~cm}$

Coleção particular 
O beijo não ocupa posição estratégica na obra de Senise casualmente. É uma pintura capaz de sintetizar muitos dos aspectos que sua obra tangencia. Sua trajetória, por sua vez, é de certa forma uma síntese de sua geração. É emblemática não só no que diz respeito aos aspectos mais históricos e de época, mas também às características que ele e seus contemporâneos passaram a compartilhar depois que suas obras decantaram, isto é, depois que foram se despedindo daquilo que era mais datado, fruto da explosão e da comoção em torno ao fenômeno midiático chamado "Geração 80", para abraçar inquietações mais aprofundadas.

O beijo, marca de intimidade e afeto, abre portas para uma possibilidade narrativa que diz muito sobre a arte produzida no período e aproxima Senise de Adriana Varejão, Beatriz Milhazes e Nuno Ramos. À carga expressiva e à relação com a morte, duas matrizes do diálogo constante entre Senise e Angelo Venosa, se soma um dado ainda pouco estudado pelos críticos e historiadores da arte: a palavra espelhada no canto esquerdo da tela. Se o uso do verbo evoca a obra de Leonilson, grande amigo com quem Senise manteve uma relação de admiração mútua, também nos leva para artistas estrangeiros muito próximos da pintura do artista, caso do alemão Anselm Kiefer, influência e diálogo inegáveis, e do argentino Guillermo Kuitca. Não se trata de uma palavra qualquer: "ANGE" insinua "anjo" ou "angelus" - e sua inversão, depois do beijo infinito da morte, pode nos levar para o campo oposto. "ANGE" também são as quatro primeiras letras de "Angelina", nome da mãe do artista, figura importante de sua biografia e que também é citada em um trabalho anterior: Beddangelina, de 1989, representa um cisne - forma "roubada" da tampa de um vidro de perfume - de cabeça para baixo.

A mãe e outras figuras de mulher estão em pinturas como Levitação (1995), Meninaossocão (1994), Mãe e filho (1996) e no trabalho site-specific Eva (2009-2010), feito para o Centro Cultural São Paulo. A imagem associada ao feminino também está presente em Ela que não está (1994). Nesta série, Senise se debruça, repetidamente, sobre a marca que uma lápide deixou em um afresco pintado por Giotto na Igreja de São Francisco, em Florença. "Ela" é a própria arte e sua(s) história(s); "ela", como Eva, a personagem bíblica e arquetípica, entra no curso criativo do artista como uma dor latente e um desvio; "ela" é a imagem ausente.

Com Ela que não está, Senise deixa paulatinamente a figuração de maneira explícita. Fica claro ainda seu abandono da pintura — no sentido tradicional, com pincel e tinta sobre tela — rumo a um questionamento cada vez mais profundo a respeito das questões que definem 
e constituem a linguagem pictórica. Ela que não está é, aliás, uma encruzilhada de reflexões sobre pintura, representação, História, arquitetura e memória. É emblemático que o artista escolha retratar uma falta justamente no afresco daquele que é considerado o primeiro dos pintores do Ocidente, espécie de pai e de berço de todos os pintores que viriam depois: Giotto.

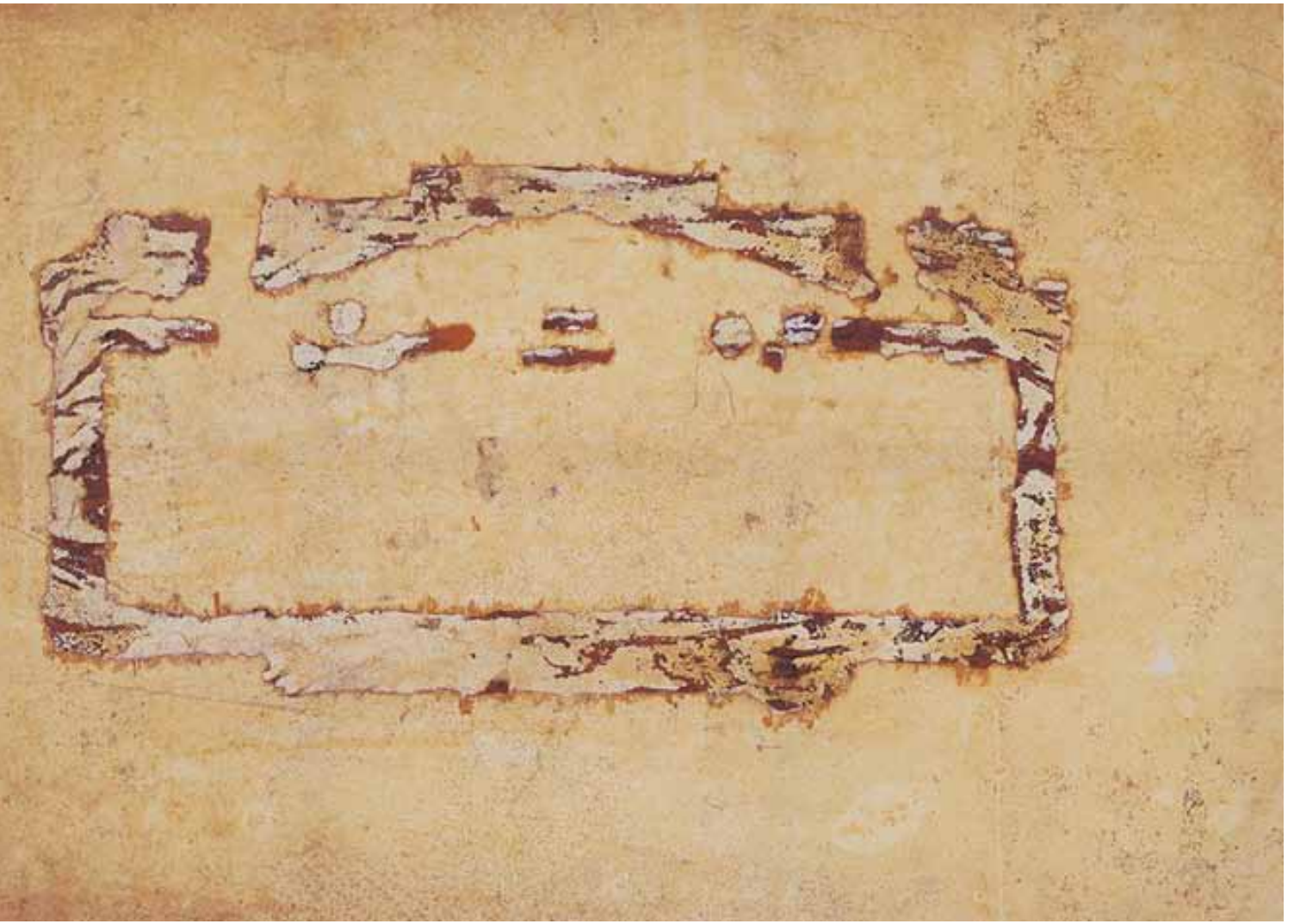

\section{Daniel Senise}

Ela que não está, 1994

Verniz poliuretânico, pó de ferro e laca sobre cretone, $193 \times 305 \mathrm{~cm}$

Coleção particular 
A síntese se completa com o fato de que a imagem que falta é uma marca deixada por uma sepultura: depois da anunciada "morte da pintura", Senise conversa com seu fantasma com bastante naturalidade. Há neste diálogo uma marca comum a seus contemporâneos: na geração que despontou nos anos 1980, é possível notar uma postura menos edipiana em relação às heranças de períodos anteriores, incluindo aí o modernismo brasileiro, ainda muito reverente à Europa e às tradições acadêmicas do século XIX. Os pintores dos anos 1980 parecem resolver bem a equação entre ruptura e apropriação, verificando que não é preciso matar a representação - assassinar o pai da tradição, como fez o filho de Jocasta - para romper com ele. Como um Hamlet, Senise conversa com o espectro deste pai, caminhando sobre as ruínas. Se Luiz Zerbini, outro pintor do período nos lembra, em uma pintura de 1994, que O Hamlet contemporâneo não segura a caveirinha não, é certo que, para esta geração de artistas, os supostos mortos ainda importam, bem como suas aparições fantasmáticas.

Senise é um artista emblemático para que se compreenda aquele que talvez seja o maior empreendimento da chamada "Geração 80". A volta de uma relação mais íntima e direta com a imagem, posta em xeque nas décadas anteriores, é muito mais relevante do que uma mera "volta à pintura", a recuperação entendida como conservadora e vazia pelos que analisaram o período de forma superficial, apressada e preconceituosa. A obra de Senise faz o elogio dessa nostalgia da imagem, preterida pelas décadas de desmaterialização e abstração. Uma imagem que ainda é esmagada, contraditoriamente, pela grande oferta de imagens da contemporaneidade.

Os anos 1980 foram um período significativo para esta ampliação de oferta no mar de imagens, o que vem dificultando cada vez mais no discernimento daquelas imagens que realmente importam: a convivência com uma grande profusão de imagens na vida cotidiana e doméstica. Com o PC - personal computer - , o computador foi parar dentro da casa das pessoas. Foi a década do videogame Atari, do controle remoto e do videocassete. Eleger imagens passa a fazer muito sentido para a estruturação de algum pensamento em torno da pintura. E Senise destaca a imagem que importa ao ocultá-la, retirando-a dos olhos para ativá-la na memória de quem se posta diante de um de seus trabalhos. A pintura do artista é ao mesmo tempo produto e resposta à profusão de imagens a partir do século XX. Se por um lado o raciocínio da fragmentação permanece, com a pintura como testemunha de uma espécie de naufrágio, as imagens escolhidas pelo pintor são como as mensagens na garrafa enviadas por aquele 
que está à deriva. As imagens escolhidas, eleitas em meio ao maremoto de tantas outras, são realçadas muito mais por não estarem ali - ou por aparecerem transfiguradas, citadas, modificadas - do que por uma representação direta, usual.

Como a imagem apagada pela sepultura no afresco de Giotto, as pinturas de Senise são como aqueles afogados que o mar carrega, e cujo corpo pode permanecer para sempre sem sepultamento. Vez ou outra os corpos são devolvidos em uma praia distante, desfigurados por conchas, algas e outras criaturas marinhas, familiares e irreconhecíveis a um só tempo. Este estranhamento e esta sensação de exílio fazem parte da obra do artista desde o início de sua carreira. Na exposição Como vai você, Geração 80?, de 1984, Senise apresentou uma tela monumental projetada especialmente para o vão entre as duas colunas em frente à piscina do Parque Lage. Sansão representava o herói bíblico de força descomunal, empurrando as duas colunas. A forma do corpo deste homem com pernas e braços disformes, lembra a das figuras de Tarsila do Amaral na fase do Abaporu e da Antropofagia. Dentro de um espírito da época, tanto o personagem quanto o grafismo perto de sua cabeça e de seus braços evocam o traço das histórias em quadrinhos, um dos muitos produtos da cultura pop que se infiltraram na arte deste início dos anos 1980, dominado por retículas, cores fosforescentes, raios e os anjinhos de óculos escuros da grife de roupas Fiorucci.

Além de trazer este DNA de seu tempo, Sansão já diz muito sobre o próprio Senise. A forma do tronco - dos ombros até a região pélvica - lembra os corações e formas marinhas e vegetais que estariam em outros trabalhos da mesma época. O aspecto formal não é tudo: já há, nesta pintura gigantesca, a relação direta com a arquitetura (que há em toda pintura, é claro, mas que é citada e destacada na obra de Senise). Há ainda a presença de um herói trágico, traído pela mulher que amava, Dalila. Ela descobre que o segredo de sua força está nos cabelos e entrega Sansão aos filisteus. Ele acaba preso, cego e torturado pelos inimigos.

Ruínas, paisagens ermas e personagens solitários ou decadentes são algumas das marcas do romantismo, tanto na literatura quanto na pintura. Senise se aproxima destas características, dando a elas novo vigor, povoando suas telas seminais com restos de colunas arquitetônicas, ossos e animais de grande carga simbólica, como cisnes, elefantes e golfinhos. Tudo parece vestígio e encenação de um mundo que foi deslocado para outro lugar; um mundo que já não há. O início da frase anterior, "Tudo parece vestígio," poderia até ser desmembrado em duas 
partes para falar da obra do artista. Em Senise, "tudo parece." Em Senise, "tudo é vestígio".

Esta pintura que ora dá a impressão de ser épica, ora pode olhar cinicamente para a História, é definida por Wilson Coutinho como o "teatro das sensações mutiladas" (1985, p.6). O crítico diz ainda que é como se os quadros de Senise vivessem assombrados por "uma atmosfera de catástrofe e de terror noturno". Anos mais tarde, Coutinho revisitaria o trabalho do artista e comentaria o cisne de Beddagenlina e a tampa de perfume no formato da ave, feita de borracha, que ficou anos no ateliê do artista, e acabou indo parar na tela. Esta é uma obra que pode ser uma boa porta para as pinturas dos primeiros anos de carreira do artista, especialmente aquelas que fizeram parte da 'Grande tela' proposta pela curadora Sheila Leirner na Bienal Internacional de São Paulo de 1985. Este processo de escavação da tela, com sua espessa camada de tinta, e de sepultamento/exumação da imagem, foi comparado por Dawn Ades ao gesto romântico de "se perpetuar pela construção de tantos monumentos, pela escavação de tantos túmulos", pretexto para "prolongadas meditações sobre a mortalidade, a passagem das eras e o declínio das civilizações". (1998, p.23).

\section{Silhuetas}

Se tangencia este impulso expressivo e romântico, Baddangelina, o cisne-mãe, avesso da imagem, também é boa vereda para trilharmos outro aspecto importante nesta trajetória: o uso das silhuetas. Uma silhueta é o negativo de uma imagem. Mais do que uma sombra, a silhueta é uma falta, mas sem qualquer profundidade. Evidencia um jogo entre a mancha e a linha, dois elementos constitutivos básicos da história da pintura. Uma silhueta é mancha, corpo de uma forma, ou evidência de seu contorno? No caso de Meninaossocão (1994) e Paisagem com levitação (1995), as duas coisas.

Em Paisagem com levitação, a moça que paira sobre um descampado, como em um número ilusionista de Houdini, é coberta por uma camada de verniz poliuretânico, conhecido como "asa-de-barata", material capaz de criar a opacidade misteriosa que cobre a figura. É possível enxergar este véu branco sobre a imagem de muitas formas. Ele pode ser um vestígio de gozo, sêmen fertilizando a cena. Pode ser lembrança do mar, com o sal cristalizando e erodindo as imagens encalhadas. Pode se referir ainda a um borrão da memória, que opera o tempo inteiro enterrando (o melhor verbo seria, talvez, afogando, para lembrar Bergson) e exumando 
as imagens que vemos. As silhuetas, lembrança do estêncil e do carimbo, mas também da junção entre linha e cor feita pela tesoura de Matisse, são arquivo: imagens guardadas e acessadas aos lampejos. De outras maneiras, este arquivo de afetos, codificado como uma antologia das imagens que importam, aparece nos processos de trabalho de Zerbini, Milhazes, Leonilson e Varejão, entre outros artistas brasileiros contemporâneos de Senise.

Em Meninaossocão, as três figuras entram na composição de forma a sugerir múltiplas interpretações. Se por um lado o osso parece delimitar campos opostos, por outro a menina e o cachorro estão fincados em seus próprios chãos, como se a tela tivesse dois apoios, em campos opostos - numa curiosa inversão dos eixos vertical e horizontal. O tratamento do fundo, que cria um campo mais claro e arredondado na área das figuras, sugere um terreiro, mas também um redemoinho. Na diagonal, o osso lembra uma barra de travessão, o que poderia nos levar para a obra psicanalítica de Lacan, se este fosse o propósito do artigo, mas também nos abrir a possibilidade de ler as três imagens como uma espécie de escrita - tanto uma frase, o que joga Senise no campo da narração quanto no de uma equação matemática.

A silhueta aparece ainda nas pinturas em que Senise se aproxima de imagens da história da arte, como fica claro na série criada a partir de Arranjo em cinza e preto no. 1 (1871), conhecida como "Retrato da mãe do artista" e pintada por James Whistler (1834-1903). No seu primeiro Retrato da mãe do artista (1992), Senise usou uma técnica de impressão desenvolvida por ele e batizada informalmente de "sudário": a ferrugem desprendida de dezenas de pregos depositados na superfície da tela é que dá forma à silhueta da mãe "roubada" de Whistler. O uso do prego amplia os significados da técnica do "sudário", desenvolvida pelo artista no fim dos anos 1980. Senise havia recebido uma encomenda de um cenário teatral sobre a Paixão de Cristo, mas o espetáculo jamais seria realizado. A ideia do sudário, de um tecido impressionado com o rosto de um corpo morto - monotipia e silhueta - ficou em sua cabeça. Tempos depois, trabalhando em seu ateliê, uma pintura cuja superfície já havia sido pintada ficou grudada pelo verso no chão. Quando o artista conseguiu soltá-lo, viu que a tela trazia as marcas do piso. A partir daí, o "sudário" foi explorado de múltiplas maneiras. Na série de trabalhos arquitetônicos dos anos 2000, que será retomada adiante, a impressão vinda do chão atinge seu ápice, com uma operação metonímica que reconstrói os espaços - museus, galerias, galpões - a partir dos vestígios de seus pisos. E que opõe a verticalidade da arquitetura ao mais horizontal de seus planos: o chão. 
No primeiro trabalho da série Retrato da mãe do artista, o prego aparece com sua forma definida, como silhueta do corpo que esteve sobre a superfície da pintura. Nesta mesma época, os cadernos de anotação do artista, que são praticamente um segundo ateliê, registravam anotações sobre o filme A última tentação de Cristo, adaptação de Martin Scorsese para a obra de José Saramago. Senise recortou do jornal uma foto do ator William Dafoe caracterizado como Jesus, usando a coroa de espinhos antes da crucificação. Sim, antes do sudário veio a cruz, e com ela vieram os pregos. Há um código interno evidente na obra do artista. Também há, no prego, uma relação com a história da arte e da imagem. A pintura dos artistas dos anos 1980 tem um impulso catalogador, que elege as imagens que importam em meio ao tsunami de imagens possíveis. Usar pregos na silhueta da mãe de Whistler pode ser uma tentativa de fixar uma imagem fugidia. Imagem que é fantasma, mas é relevante; dor latente.

A característica espectral da mãe, da História e da pintura na obra de Senise fica mais clara na segunda tela da série, em que a tinta acrílica é usada como único material que cobre o tecido, sem os pregos ou qualquer outro elemento. Em vez da silhueta da mãe sentada, o que se vê é um volume, no formato da mulher em sua cadeira, mas que aparece coberto por um pano branco. Este fantasma de Whistler é uma forma que emerge de um fundo negro, cheio de informações inclassificáveis de impressão, trabalhado como "sudário". Hamlet volta a conversar, entre a desconfiança, a reverência e o delírio, com a figura do Rei morto.

No interior do Brasil e em outras culturas, é comum cobrir os espelhos quando alguém morre. Acredita-se que assim a passagem para outro plano é facilitada, pois a imagem do ser querido, aprisionada no espelho, não tem a oportunidade de voltar para este mundo. A mortalha do espelho não é do corpo, é da imagem, assim como a que Senise tece, em sua pintura, para a pintura de Whistler. Falar de espelho - e da crença popular de que ele é um canal para a comunicação com outras dimensões - é bastante oportuno no trato com esta série de trabalhos. Em Despacho (1993), Senise volta à silhueta da mãe, mas ela é duplicada e invertida. A mãe olha para outra versão dela mesma enquanto a olhamos. A "tinta" é óxido de ferro, mas desta vez os pregos não aparecem em sua forma, apenas se aproveita seu pó, que não deixa de ser uma mortalha. Há, no entanto, a pequena silhueta da cabeça de um martelo no fundo, como uma porta se abrindo para a memória daquilo que pousou ali. Despacho origina outros trabaIhos, criados a partir do espaço negativo entre as mães. Senise traça uma linha imaginária (ou imaginada) entre as cabeças das duas figuras, unindo-a ao contorno dos corpos, até os pés. 
Surge então o desenho de uma fonte ou chafariz, que é trabalhada em duas telas sem título no jogo entre positivo e negativo da silhueta. A fonte poderia ser também um vaso ornamental ou a genitália de uma mulher. Somadas à imagem original, de mãe, estas possibilidades reforçam a relação com a origem e com aquilo que é feminino. A mãe é origem; a silhueta, imagem-zero. Com elas, Senise parece estar trazendo as ruínas da história da arte para um ponto de fim de ciclo, que também é um reinício.

Há um incontornável viés afetivo nesta relação com a imagem. Do mesmo modo que Zerbini pinta seus amigos e seus amores, Senise se aproxima daquilo que seu olho, meio scanner, um dia entendeu como importante. A imagem eleita tanto pode ser um anúncio de panelas, 'sampleado' e mixado ao Juízo final (1535-1541), de Michelângelo (1475-1564), quanto pode ser a matriarca de um cânone da pintura, fragmentada e com suas partes "repregadas" em novos sentidos, expostos ao tempo com o óxido de ferro. Se a pintura morreu, esta é uma obra que reivindica o papel de inventário dessa morta.

\section{A mãe, a casa: ninhos}

A ferrugem é matéria-prima perfeita para a união desse mundo dos mortos - ou da morta, que é a pintura - com a vida que ainda corre no presente. O prego, corpo que morre para pintar, contamina o aspecto formal das pinturas do artista, ampliando as noções de vestígio, sudário e memória do corpo. Com os pregos, Senise criou outro trabalho importante de sua carreira: Quase infinto (1992).

Quase infinito cria um intenso diálogo especular: Senise encontra Senise, ao revisitar O beijo do elo perdido. O infinito que não se fecha, fluxo interrompido, tem a forma dos dois crânios de pássaros. Quem conhece uma obra lembra-se da outra e vice-versa. O "quase", que interrompe o fluxo do infinito, também é um emblema desta obra que fala de uma coagulação de tempos, de suspensão de um fluxo avassalador de informações para que se pregue à pintura algumas das imagens que importam. Em A sobrevivência dos vaga-lumes, Didi-Huberman fala sobre as possibilidades de resistência da cultura e da imagem na pós-modernidade. A obra dos pintores da chamada "Geração 80" reflete a fragmentação e certa espetacularização da vida contemporânea. Poderia, em uma análise apressada, se assemelhar ao que Huberman chama de holofote, uma luz autoritária e acachapante. Mas os pintores dos anos 
1980 também procuram virar a fragmentação e o espetáculo pelo avesso, fazendo com isso uma desmontagem e uma ressignificação. Estes artistas fazem também uma pintura "vaga-lume", que procura dar sobrevida e lançar nova luz, ainda que intermitente e indefinida, na direção da imagem.

Senise é um vaga-lume a partir ausência. No piscar da luz, o momento em que ela se apaga pode ser mais revelador do que aqueles de clarão. Ela que não está é uma síntese deste procedimento. Na série sobre a marca da lápide no afresco de Giotto, o artista representa a não imagem, flertando com este paradoxo. Na falha causada pela sepultura, a imagem foi construída a partir de algo que havia sido arrancado de uma superfície. Ela que não está nos leva à lembrança da pintura - e do pintor que inventou, por assim dizer, a pintura como atividade artística - através da arquitetura. Na série de espaços virtuais que o artista passa a construir nos anos 2000, a partir de tecidos impressionados com o material contido no piso destes ambientes, Senise reergue a arquitetura com pintura, e uma pintura que tem como matéria-prima o vestígio da própria arquitetura. Outro trabalho impressionante que aponta para a relação com a arquitetura é Vai que nós levamos as partes que te faltam (2008), em que Senise reproduz, minuciosamente, em aquarela, cada taco do piso do corredor de sua casa. O título retirado de um trecho de Terra sonâmbula, novela do moçambicano Mia Couto, dá uma pista de que esta obra é um caminho de volta: é como se o artista devolvesse ao chão aquilo que tomou emprestado, ao longo de mais de duas décadas fazendo pinturas do piso a partir da técnica do "sudário". Se o piso pode ser matriz e pigmento para sua pintura, antiteticamente sua pintura pode também representar o piso, com todos os seus detalhes.

A ideia de casa se assemelha às imagens de mulher e de mãe: ambas são abrigo. Recentemente, trabalhos de site-specif têm ganhado importância em sua obra, ajudando-o a sintetizar e a realçar estas inquietações. Em 2011, o artista apresentou, na Casa FrançaBrasil, no Rio de Janeiro, o trabalho 2892. Construiu uma espécie de corredor, cujas paredes eram formadas por lençóis doados para hospitais e motéis e devolvidos ao artista depois de bastante usados. Higienizados, estes tecidos preservavam, no entanto, as marcas de seu uso: inscrições para identificação, rasgos, cerzimentos. Traziam ainda a imantação dos corpos daqueles que haviam se deitado sobre eles, numa atualização do "sudário". 
O corredor de lençóis transformava a grande praça que caracteriza o espaço central da Casa França-Brasil, antiga Alfândega do Rio, em uma nave de igreja. O visitante percorria, metaforicamente, uma via crucis diferente da de Jesus, mas que acarretou em outros sudários de morte, agonia e transfiguração de um objeto em obra de arte (DANTO, 2010). Esta relação com a Paixão de Cristo era reforçada pelo trabalho que ocupava, solitário, a pequena Sala do Cofre do centro cultural. Em Crufixão (2011), Senise se apropria da imagem ausente da tela homônima de Matias Grün em uma página livro, marcada pelo lugar de onde a ilustração foi arrancada. O corpo ausente de Cristo morto de Grün, sugerido apenas pela legenda da imagem, ecoa nos corpos ausentes dos lençóis.

Antes da França-Brasil, o artista realizou outro site-specific de máxima importância: Eva, trabalho que foi criado aos olhos do público, entre o fim de 2009 e o início de 2010, no Centro Cultural São Paulo (CCSP). O artista se apropriou da escultura Eva (1919), de Victor Brecheret (1894-1955), e foi cobrindo-a paulatinamente com quatro muros de tijolos feitos com imagens de arte. Triturava refugos de catálogos e sobras de convites e folders de outras exposições, mesclava esta farofa de imagens ao gesso e fazia tijolos. Uma olaria para criar estas peças foi criada dentro da instituição, e funcionava sob o testemunho dos visitantes. Apesar de ter sido pouco observado pela crítica, por ser um trabalho recente e também por não se configurar como uma pintura, Eva significa uma lufada de frescor e ao mesmo tempo uma dobra na história de Senise.

Há três caminhos muito importantes sustentando este trabalho: o primeiro deles é traduzido pelo refugo dos convites. Os restos de imagem, as bordas da memória e as heranças fragmentadas da história da arte, sustentados paradoxalmente pela ausência, são capitais na obra de Senise. O segundo ponto tem a ver com esta mãe/ mulher e a não-imagem, a falta. Encobrir Eva, a primeira mulher, não é um gesto pouco significativo para alguém que criou a série Retrato da mãe do artista. Também não é trivial para alguém que tem em outra série, Ela que não está, um dos marcos de sua trajetória. A mãe e a falta apontam para o mesmo lugar - o da pintura, o da imagem. O terceiro ponto é o mais evidente, mas nem por isso menos importante: a relação da obra de Senise com a arquitetura - a história dela ao longo dos séculos e o próprio espaço/escala onde cada obra nova está inserida. Os trabalhos criados em Nova York nos anos 2000, com a memória do chão, mostram é uma característica cada vez mais entranhada em sua obra. 


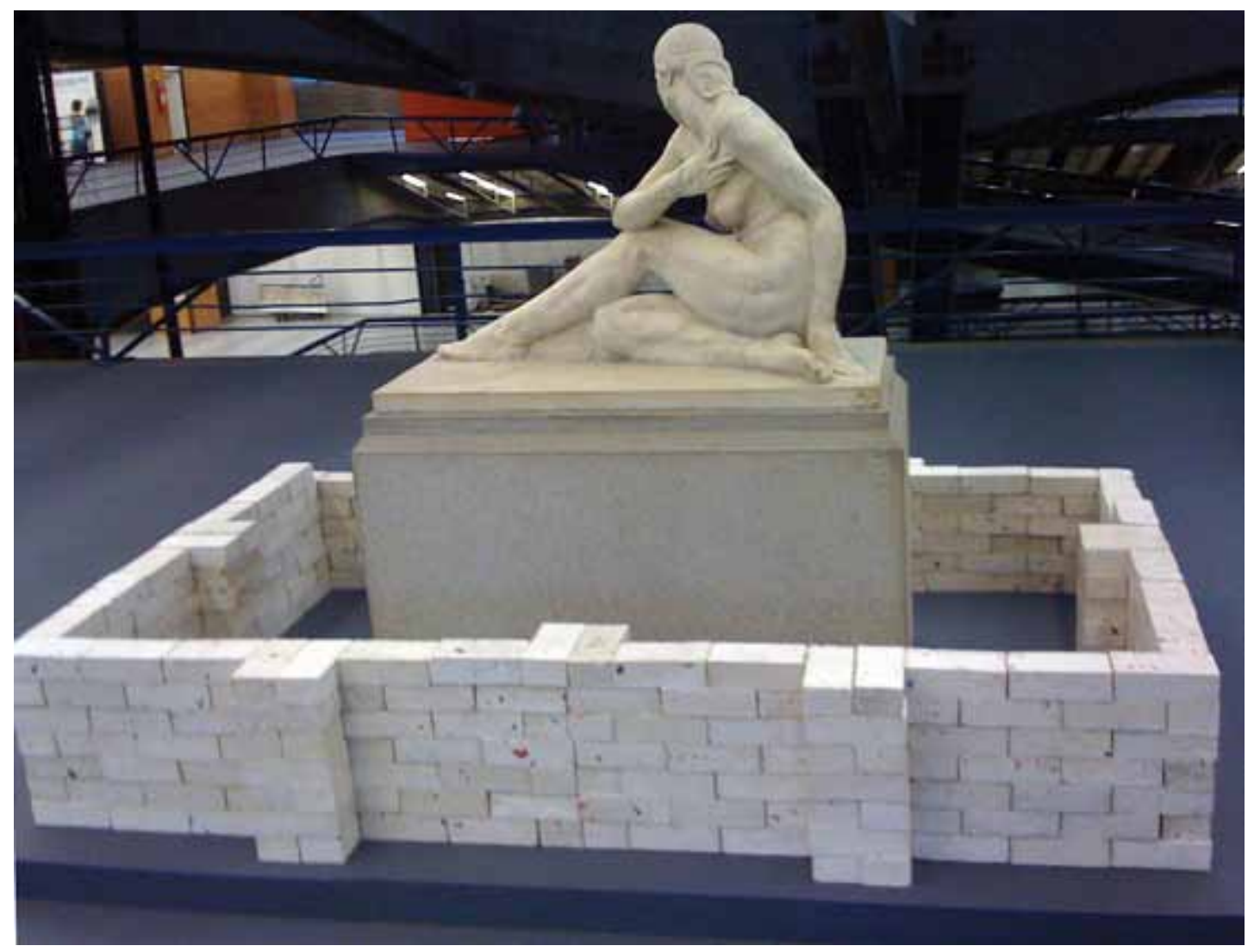

Daniel Senise

Eva, 2009-2010

Site-specific para o Centro Cultural São Paulo

Tijolos feitos de convites e folders de exposição cobrem a obra Eva, de Victor Brecheret

Não deixa de ser curioso que Senise evidencie questões importantes de seu trabalho ao expandir a pintura rumo ao espaço. Há aí a lembrança de que a pintura nasceu fora da tela: estava na parede das cavernas, nos afrescos, nos tetos renascentistas e nas iluminuras antes de ganhar portabilidade e possibilidades domésticas através de seu enquadramento. É interessante ver que, ao devolver esta pintura para o espaço e para o mundo, expandindo-a e tornando-a inclassificável e mestiça, estes artistas aguçam suas características. 
Parede com 5 buracos (2013) é um trabalho exemplar para que se fale desta devolução das imagens ao fluxo do mundo - e também sobre a capacidade de um artista já maduro, como Senise, de estabelecer diálogos internos com sua própria obra. A instalação recebia o público na exposição Travessias, montada no Galpão Bela Maré, no Complexo de Favelas da Maré, no Rio de Janeiro. A obra de fato consistia, à primeira vista, de uma parede branca, com cinco buracos, parecidos com os "olhos mágicos" de uma porta. Experimentar cada um deles era descobrir a réplica perfeita, em maquete, de salas de quatro importantes museus: o Museu d'Orsay, em Paris; o MoMA, em Nova York; a National Gallery, de Londres; e o Museu de Arte Moderna, do Rio de Janeiro. No quinto e último buraco, o espectador era convidado a descortinar, como um voyeur olhando pela fenda da fechadura, o próprio Galpão da Maré, olhando através de Senise o trabalho de outros artistas participantes da mostra, caso de Ernesto Neto, Carlos Vergara, Arjan e Luiza Baldan.

Assim como Vai que nós levamos as partes que te faltam pode ser vista como uma resposta ao chão, com Parede com 5 buracos Senise devolve ao olho as imagens eclipsadas ao longo de seus mais de 30 anos de carreira. O buraco - que já foi marca da ausência em Ela que não está e espaço negativo nas silhuetas - é virado do avesso. A obra que engoliu as imagens, ocultando-as para que nós lamentássemos sua ausência, agora as reintegra ao olho, com fartura e generosidade. Há um regurgitar e um trânsito cíclico e heterogêneo. Somos hoje banhados por um mar superpovoado de imagens. Na vida em rede, é difícil pescar as que importam. Na devolução das imagens aos seus arquivos-museus, erguidos como maquetes - miniaturas de um lugar - , Senise leva mais uma vez a arte de volta para casa, para o colo e para o ninho. Ao olhar pelo olho mágico, o observador descortina a possibilidade de o abrigo da arte poder ser também o seu corpo, sua experiência e a sua memória.

Artigo recebido em julho de 2015 e aprovado em agosto de 2015.

\section{Referências}

ADES, Dawn. Daniel Senise: vestígios. In: Ela que não está. São Paulo: Cosac Naify, 1998.

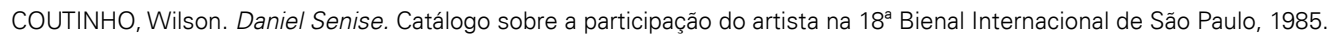

BERGSON, Henri. Matéria e memória. São Paulo: Martins Fontes, $2^{a}$ edição, 1999 [1896].

DANTO, Arthur C. A transfiguração do lugar-comum: uma filosofia da arte. São Paulo: Cosac Naify, 2010 [1981].

DIDI-HUBERMAN, Georges. A sobrevivência dos vaga-lumes. Belo Horizonte: Editora UFMG, 2011 [2009]. 